\title{
Pengaruh Kecerdasan Spiritual Dan Perilaku Etis Terhadap Komitmen Organisasional Pada PT. Pegadaian Persero Cp Karombasan - Manado
}

\author{
Shysilia Rennarda Sumual \\ Roy Runtuwene \\ Wehelmina Rumawas \\ Program Studi Administrasi Bisnis, Jurusan Ilmu Administrasi \\ Fakultas Ilmu Sosial dan Politik, Universitas Sam Ratulangi \\ shysilia.sumual@gmail.com
}

\begin{abstract}
This study aims to examine the Effect of Spiritual Intelligence and Ethical Behavior on Organizational Commitment at PT. Pegadaian Persero CP Karombasan - Manado. The population in this study were employees of PT. Pegadaian Persero CP Karombasan Manado. The study sample used Genuine Sampling, the data sources were primary and secondary. The data analysis technique used is validity test, normality test, reliability test, multiple linear regression analysis, and coefficient of determination analysis, $t$ test hypothesis and $F$ test. The results of this study indicate that partially ( $t$ test) spiritual intelligence has a significant effect on organizational commitment with it is known that the value of $t$ count is greater than $t$ table. Ethical behavior does not significantly influence organizational commitment with the value of $t$ calculated less than the value of t table. Based on the results of the $F$ test it can be concluded that spiritual intelligence and ethical behavior have a significant effect on organizational commitment, this can be seen from the calculated $F$ value greater than $F$ table.
\end{abstract}

Keywords: Spiritual Intelligence, Ethical Behavior and Organizational Commitment.

\section{Pendahuluan}

Perkembangan dunia usaha di Indonesia sangatlah cepat, dan yang menjadi salah satu faktor pendukungnya adalah banyaknya Sumber Daya Manusia yang saling berkompetisi. Sumber Daya Manusia yang cerdas dan mempunyai perilaku etis merupakan faktor penting yang mempengaruhi tercapainya tujuan perusahaan. Sesuai dengan penelitian yang dilakukan oleh Rumawas (2018) Sumber Daya Manusia dalam konteks bisnis adalah seorang yang bekerja dalam suatu organisasi atau yang sering juga disebut karyawan, merupakan aset paling penting yang harus dimiliki oleh organisasi dan harus diperhatikan dalam manajemen, karena mereka inilah yang bekerja membuat tujuan, mengadakan inovasi dan mencapai tujuan organisasi. Menurut data dalam www.pegadaian.co.id di tahun 2017 terdapat 237 orang yang mengundurkan diri, sedangkan di tahun 2016 terdapat 104 orang yang mengundurkan diri dari PT. 
Pegadaian Persero. Dapat dilihat dari data ini bahwa komitmen organisasional di PT. Pegadaian Persero menurun karena semakin meningkatnya karyawan yang melakukan pengunduran diri dengan penyebab yang berbeda-beda dari setiap orangnya bisa disebabkan karena faktor internal maupun faktor eksternal dari setiap karyawannya. Dan terdapat fraud dalam PT. Pegadaian Persero yang dilakukan oleh pegawainya. Dibuktikan dengan surat putusan pengadilan mahkamah agung terkait fraud pegadaian diantaranya Nomor Putusan: No:02/Pid.Sus/2013/PT.TPK.Smg dengan nama tersangka Ahmad Faozan Bin Mashudi dengan modus Fraud membuat 95 Surat Bukti Kredit/SBK fiktif yang diketahui telah dipergunakan oleh terdakwa untuk mencairkan pinjaman dari Pegadaian Cab. Pati dengan kerugian sebesar Rp.274.660.000,--

PT. Pegadaian Persero CP Karombasan - Manado memiliki jumlah karyawan sebanyak 33 orang dan 14 diantaranya adalah security. Terdapat beragam karakter individu didalamnya, dan memiliki rasa loyalitas yang berbeda pada perusahaan. Meskipun didalamnya terdapat security dengan jumlah yang cukup banyak namun tidak menjamin akan dapat secara langsung mengatasi fraud yang ada didalam kantor, dikarenakan sistem penjagaan yang dilakukan oleh security bersifat penjagaan kantor tidak sampai kesistem yang bisa dilakukan pegawai diluar security.
PT. Pegadaian Persero secara keseluruhan mempunyai masalah dalam komitmen organisasional baik dalam pengunduran diri yang dilakukan setiap pegawainya maupun perilaku yang tidak etis yang dilakukan oleh setiap pegawai yang ada. Keberagaman dan sistem inilah yang harus dikelola agar setiap karyawan yang ada bangga menjadi karyawan, bahkan setia menjadi karyawan di PT. Pegadaian Persero. Dalam hal ini apakah faktor-faktor pendukung yang terurai dalam penjelasan diatas dapat mempengaruhi agar hal tersebut dapat terjadi.

\section{Kecerdasan Spiritual}

Menurut Trihandini (2005) indikatorindikator dalam Kecerdasan Spiritual, yaitu: (1) Mutlak jujur dalam arti berkata benar dan konsisten akan kebenaran; (2) Keterbukaan ialah bersikap fair atau terbuka; (3) Pengetahuan diri; (4) Fokus pada kontribusi yang mengutamakan memberi daripada menerima.

Kecerdasan Spiritual (Zohar dan Marshall, 2009) merupakan kecerdasan yang dipakai individu untuk merengkuh makna, nilai, tujuan terdalam, dan motivasi tertingginya. Individu yang kecerdasan spiritualnya telah berkembang dengan baik juga mampu mengenali dirinya sendiri dan mengembangkan pemahaman motivasi yang terdapat dalam dirinya. 


\section{Perilaku Etis}

Perilaku etis merupakan perwujudan dari etika yang diimplementasikan di dalam organisasi bisnis. Perilaku etis pada umumnya bisa didefinisikan sebagai perilaku yang dianggap benar atau salah, dan karenanya mengarahkan apa yang boleh dan tidak boleh dilakukan orang (Beauchamp dan Bowie, 2002) dalam Pio (2015).

Trevino, Weaver dan Reynold (2006) menuliskan Perilaku Etis tidak terlepas dari nilai-nilai yang menjadi keyakinan karyawan. Pentingnya perilaku etis pada organisasi sudah semakin nyata, karena banyak penelitian terbaru sudah menghasilkan pengetahuan yang terkait dengan manajemen, khususnya Perilaku Etis individu di dalam organisasi.

\section{Komitmen Organisasional}

\section{Luthans (2006) Komitmen}

Organisasional merupakan sikap yang merefleksikan loyalitas karyawan pada organisasi dan proses berkelanjutan di mana anggota organisasi mengekspresikan perhatiannya terhadap organisasi dan keberhasilan serta kemajuan yang berkelanjutan.

Tubbs dan Dahl (1991) dalam Rumawas (2015) mencoba menggali efek komitmen pada hubungan kinerja, dengan asumsi bahwa pekerja yang berkomitmen lebih siap untuk mencapai tujuan organisasi daripada pekerja yang tidak berkomitmen. Model Penelitian

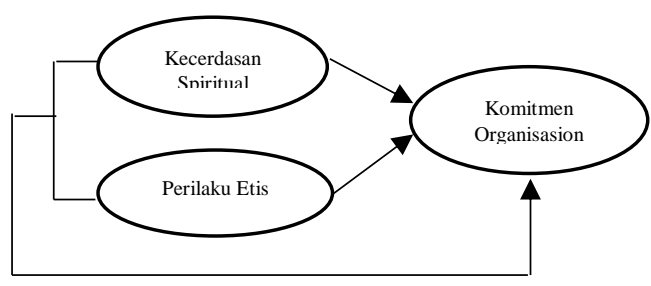

Gambar 1. Model Penelitian

Dari model penelitian ini, dapat dilihat bahwa penelitian ini bertujuan untuk melihat adanya hubungan secara parsial antara Kecerdasan Spiritual terhadap Komitmen Organisasional dan juga Perilaku Etis terhadap Komitmen Organisasional. Dan juga untuk melihat adanya hubungan secara simultan antara Kecerdasan Spiritual dan Perilaku Etis terhadap Komitmen Organisasional.

\section{Hipotesis}

Berdasarkan kerangka pemikiran, maka hipotesis yang diajukan dalam penelitian ini adalah sebagai berikut: (H1) Kecerdasan Spiritual mempunyai pengaruh secara parsial terhadap Komitmen Organisasional; (H2) Perilaku Etis mempunyai pengaruh secara parsial terhadap Komitmen Organisasional; (H3) Kecerdasan Spiritual dan Perilaku Etis mempunyai pengaruh secara simultan terhadap Komitmen Organisasional.

\section{Metode Penelitian}

Pendekatan penelitian yang digunakan pada penelitian ini adalah metode kuantitatif asosiatif. Pendekatan kuantitatif menurut Sugiyono (2010) adalah metode 
penelitian yang digunakan untuk meneliti pada populasi atau sampel tertentu, pengumpulan data menggunakan instrumen penelitian, dan analisis data bersifat kuantitatif atau statistik. Sedangkan penelitian ini menggunakan tipe atau jenis penelitian asosiatif, dimana tipe penelitian bertujuan untuk mencari hubungan diantara dua variabel (Siregar, 2013).

\section{Hasil Penelitian}

\section{Hasil Uji Validitas}

Dari hasil output Uji Validitas variabel Kecerdasan Spiritual dinyatakan bahwa hanya ada beberapa item yang valid karena nilai item atau $r_{\text {hitung }}$ yang lebih dari $r_{\text {tabel }}$ hanya ditunjukan oleh item 4 sebesar 0,408, item 5 sebesar 0,496, item 7 sebesar 0,855, item 8 sebesar 0,832 dan item 10 sebesar 0,655. Kemudian hasil output Uji Validitas variabel Perilaku Etis dinyatakan bahwa hanya ada beberapa item yang valid karena nilai item atau $r_{\text {hitung }}$ yang lebih dari $r_{\text {tabel }}$ hanya ditunjukan oleh item 3 sebesar 0,869, item 6 sebesar 0,565, item 7 sebesar 0,665 dan item 8 sebesar 0,983. Dan hasil output Uji Validitas variabel Komitmen Organisasional dinyatakan bahwa hanya ada beberapa item yang valid karena nilai item atau $r_{\text {hitung }}$ yang lebih dari $r_{\text {tabel }}$ hanya ditunjukan oleh item 1 sebesar 0,816, item 4 sebesar 0,941, item 5 sebesar 0,389, item 8 sebesar 0,647, item 10 sebesar 0,480 dan item 12 sebesar 0,531 .

\section{Hasil Uji Realibilitas}

Dari hasil Uji Realibilitas nilai Cronbach's Alpha dari variable kecerdasan spiritual adalah 0,674 atau di atas 0,6 sehingga dapat dikatakan reliable, lalu nilai Cronbach's Alpha dari variable perilaku etis adalah 0,670 atau di atas 0,6 sehingga dapat dikatakan reliable dan nilai Cronbach's Alpha dari variable Komitmen Organisasional adalah 0,762 atau di atas 0,6 sehingga dapat dikatakan reliabel.

\section{Analisis Regresi Linear Berganda}

Berdasarkan hasil uji Analisis Regresi Linear Berganda maka diperoleh persamaan regresi sebagai berikut :

$$
\mathrm{Y}=\mathbf{2 , 8 9 2}+\mathbf{0 , 0 2 9}+(-\mathbf{0 , 0 6 1})+\mathrm{e}
$$

Persamaan regresi tersebut dapat dijelaskan sebagai berikut : (a) Konstanta sebesar 2,892; artinya jika Kecerdasan Spiritual (X1) dan Perilaku Etis (X2) nilainya adalah 0 , maka Komitmen Organisasional (Y) nilainya adalah 2,892\%; (b) Koefisien regresi variabel Kecerdasan Spiritual (X1) sebesar 0,029; artinya jika variabel independent nilainya tetap dan Kecerdasan Spiritual mengalami kenaikan sebesar 1\%, maka Komitmen Organisasional (Y) akan mengalami peningkatan sebesar 0,029\%. Koefisien bernilai positif artinya Kecerdasan Spiritual berpengaruh positif terhadap Komitmen Organisasional (Y), semakin meningkat Kecerdasan Spiritual maka semakin meningkat Komitmen Organisasional; (c) 
Koefisien regresi variabel Perilaku Etis (X2) sebesar -0,061; artinya jika variabel independent nilainya tetap dan Perilaku Etis mengalami kenaikan sebesar 1\%, maka Komitmen Organisasional (Y) akan mengalami peningkatan sebesar $-0,061 \%$. Koefisien bernilai negatif artinya Perilaku Etis tidak berpengaruh positif terhadap Komitmen Organisasional (Y), semakin meningkat Perilaku Etis maka tidak semakin meningkat Komitmen Organisasional.

\section{Analisis Koefisien Determinan}

Berdasarkan hasil uji koefisien determinasi diperoleh angka koefisien determinasi (adjusted $R^{2}$ ) sebesar 0,536 atau 53,6 \%. Hal tersebut menunjukan bahwa Komitmen Organisasional dipengaruhi oleh Kecerdasan Spiritual (X1) dan Perilaku Etis (X2) sebesar 0,536 atau $53,6 \%$, sedangkan sisanya sebesar $46,4 \%$ dijelaskan oleh variabel lain yang tidak termasuk dalam penelitian ini.

\section{Uji Hipotesis}

\section{Uji t}

Berdasarkan hasil uji t diperoleh hasil:

(1) Kecerdasan Spiritual terhadap Komitmen Organisasional. Berdasarkan hasil uji $\mathrm{t}$, diketahu nilai $\mathrm{t}_{\text {hitung }}$ sebesar 6,103 dimana hasil $t_{\text {hitung }}$ lebih besar dari $t_{\text {tabel }}(\mathrm{df}=32, \alpha=0,05)$ sebesar 1,694 atau $6,103>1,694$. Selain itu, diketahui nilai Sig dari Kecerdasan Spiritual adalah 0,000 atau kurang dari 0,05 atau 0,000 $<0,05$ maka Ho ditolak dan Ha diterima, yang artinya Kecerdasan Spiritual berpengaruh secara signifikan terhadap Komitmen Organisasional; (2) Perilaku Etis terhadap Komitmen Organisasional. Berdasarkan hasil uji $t$, diketahui nilai $t_{\text {hitung }}$ sebesar 0,115 dimana hasil $t_{\text {hitung }}$ kurang dari $t_{\text {tabel }}$ $(\mathrm{df}=32, \alpha=0,05)$ sebesar 1,694 atau $0,115<$ 1,694. Selain itu, diketahui nilai Sig dari Perilaku Etis adalah 0,910 atau lebih dari 0,05 atau 0,910>0,05 maka Ha ditolak dan Ho diterima, yang artinya Perilaku Etis tidak berpengaruh secara signifikan terhadap Komitmen Organisasional.

\section{Uji F}

Berdasarkan hasil uji $\mathrm{F}$, diketahui nilai $F_{\text {hitung }}$ sebesar 18,908 dimana nilai $F_{\text {hitung }}$ lebih besar dari nilai $F_{\text {tabel }}(\mathrm{df} 1=2$, df2 $=29$, $\alpha=0,05)$ sebesar 3,33 atau 18,908 > 3,33. Selain itu diketahui bahwa nilai Sig. pada table ANOVA adalah 0,000 atau kurang dari 0,05 atau $0,000<0,05$, maka Ho ditolak dan Ha diterima, artinya Kecerdasan Spiritual dan Perilaku Etis secara bersama-sama berpengaruh signifikan terhadap Komitmen Organisasional.

\section{Pembahasan}

PT. Pegadaian Persero CP Karombasan - Manado adalah sebuah BUMN sektor keuangan Indonesia yang bergerak pada tiga lini bisnis perusahaan yaitu 
pembiayaan, emas, dan aneka jasa dan memiliki misi salah satunya adalah memberikan service excelence dengan fokus nasabah melalui Sumber Daya Manusia yang profesional berbudaya kinerja baik, saat ini PT. Pegadaian Persero CP Karombasan - Manado sedang mengupayakan tercapainya misi tersebut dibawah pimpinan kepala cabang yang ada.

Permasalahan yang ingin dijawab dalam penelitian ini yaitu untuk mengetahui apakah Kecerdasan Spiritual dan Perilaku Etis dapat berpengaruh terhadap Komitmen Organisasional pada karyawan PT. Pegadaian Persero CP Karombasan - Manado. Berdasarkan hasil analisis mengenai Pengaruh Kecerdasan Spiritual dan Perilaku Etis Terhadap Komitmen Organisasional pada PT. Pegadaian Persero CP Karombasan Manado dengan menggunakan SPSS versi 25, uji validitas semua variabel dikatakan valid. Sehingga dapat diambil kesimpulan bahwa semua pertanyaan dala kuesioner dapat digunakan dalam penelitian ini.

Pada bagian karateristik data responden dapat dilihat bahwa responden berjenis kelamin laki-laki, responden berusia $26-35$ tahun, responden berpendidikan terakhir SMA/SMK, responden dengan masa kerja 1 -5 tahun, responden dengan tingkat pendapatan $\mathrm{Rp}$. 5.000.000 - Rp. 7.500.000, merupakan responden yang jumlahnya paling banyak atau dominan. Dari penelitian ini juga telah menghasilkan data yang sudah diolah dengan SPSS menggunakan prinsip mengkorelasikan dan menghubungkan antara masing-masing skor item dengan skor total yang diperoleh dalam penelitian ini.

Dari hasil penelitian yang sudah dilakukan peneliti terdapat hubungan secara signifikan antara Kecerdasan Spiritual terhadap Komitmen Organisasional, hal ini sejalan dengan penelitian yang dilakukan oleh L. Suhairi Hazisma (2013) yaitu adanya hubungan yang signifikan antara kecerdasan spiritual terhadap komitmen organisasional. Perbedaan yang terdapat antara kedua penelitian ini adalah terdapat variabel Kepuasan Kerja sebagai variabel intervening dan juga terdapat lokasi penelitian, populasi, dan sampel yang berbeda. Bila dihubungkan dengan landasan teori untuk variabel Kecerdasan Spiritual menurut Zohar dan Marshal (2009) Kecerdasan Spiritual merupakan kecerdasan yang dipakai individu untuk merengkuh makna, nilai, tujuan terdalam, dan motivasi tertingginya. Individu yang kecerdasan spiritualnya telah berkembang dengan baik juga mampu mengenali dirinya sendiri dan mengembangkan pemahaman motivasi yang terdapat dalam dirinya. Hal ini menunjukan ketika seorang karyawan mengasah kecerdasan spiritual yang dimilikinya untuk dipraktekan dalam dunia pekerjaan akan menambah rasa loyalitas 
pada perusahan atau rasa Komitmen Organisasionalnya.

Selanjut nya dari hasil penelitian ini juga diketahui tidak ada hubungan secara signifikan antara Perilaku Etis terhadap Komitmen Organisasional, hal ini tidak sejalan dengan penelitian yang dilakukan oleh R. J. Pio, $d k k$ (2015) yang menyatakan dalam penelitian nya terdapat pengaruh secara signifikan antara perilaku etis dan komitmen organisasional. Perbedaan hasil penelitian ini dikarenakan bedanya lokasi, populasi, dan sampel penelitian. Juga terdapat situasi atau permasalah yang berbeda diantara kedua penelitian ini. Bila dihubungkan dengan landasan teori Perilaku Etis menurut Beauchamp dan Bowie (2002) Perilaku Etis merupakan perwujudan dari etika yang diimplementasikan di dalam organisasi bisnis. Perilaku etis pada umumnya bisa didefinisikan sebagai perilaku yang dianggap benar atau salah, dan karenanya mengarahkan apa yang boleh dan tidak boleh dilakukan orang. Hal ini menunjukan bahwa seseorang yang berperilaku etis tidak sepenuhnya memiliki rasa loyalitas yang tinggi kepada perusahaan dimana dia bekerja namun tidak bisa dicondongkan kearah alasan negatif karena bisa saja karena pilihan dan peluang kerja di perusahaan lain lebih menjanjikan untuk karyawan tersebut.

Dari hasil penelitian ini, juga diketahui adanya pengaruh dan hubungan secara simultan antara Kecerdasan Spiritual dan Perilaku Etis terhadap Komitmen Organisasional, hal ini sejalan dengan penelitian dari F. R. Akbar (2016) dan R. J. Pio, dkk (2015) yaitu terdapat hubungan atau pengaruh yang signifikan antara variabel yang sama dengan yang terdapat dalam penelitian ini.

\section{Kesimpulan}

Berdasarkan hasil penelitian ini, diketahui bahwa Komitmen Organisasional dipengaruhi oleh Kecerdasan Spiritual dan Perilaku Etis secara bersamaan atau simultan. PT. Pegadaian Persero CP Karombasan-Manado adalah cabang yang tergolong memiliki wilayah kerja yang luas dan pegawai yang cukup banyak dan memungkinkan untuk melaksanakan diklat, seminar, atau pertemuan lain yang dapat membantu para pegawainya meningkatkan kecerdasan spiritual yang mereka punya dan mempertahankan perilaku etis yang mereka lakukan dalam dunia kerja.

\section{Saran}

Bagi Peniliti Selanjutnya disarankan : (a) Penelitian selanjutnya diharapkan dapat menambah variabel independen atau menambah variabel moderator atau intervening guna mengetahui variabelvariabel lain yang dapat mempengaruhi dan memperkuat variabel dependen; (b) Penelitian selanjutnya diharapkan dapat 
menambah jumlah sampel penelitian serta memperluas wilayah sampel penelitian.

\section{Daftar Pustaka}

Luthans, F. 2006. Perilaku Organisasi. Edisi Sepuluh. Yogyakarta: Penerbit Andi.

Pio, R. J. 2015. Kepemimpinan Spiritual Dimensi-Dimensi Sumber Daya Manusia. Yogyakarta: Kepel Press.

Pio, R. J., Nimran, U., Alhabsji, T., Hamid, Dj. 2015. Pengaruh Kepemimpinan Spiritual Terhadap Perilaku Etis, Kualitas Kehidupan Kerja, Kepuasan Kerja, Komitmen Organisasional dan Kinerja Karyawan. Development Research of Manajement 10, (1): 3244.

Rumawas, W. 2015. The Impact of Human Resources Development, Organizational Commitment, and Compensatioin on Employee Performance (a study conducted at Sulut Bank in North Sulawesi). International Journal of Humanities and Social Science Invention ISSN (Online): $2319-7722$ 4, (8): 26.

Rumawas, W. 2018. Manajemen Sumber Daya Manusia. Jln. Kampus Unsrat Bahu Manado : Unsrat Press.

Siregar, S. 2013. Statistik Parametik untuk Penelitian Kuantitatif. Jakarta: PT. Bumi Aksara.

Sugiyono. 2010. Metode Penelitian Kuantitatif Kualitatif dan $R \& D$. Bandung: Alfabeta.

Trevino, L. K., Weaver G. R., and Reynold, S. J. 2006. Behavioral Ethics in Organizations: A Review. Journal of Management, Vol.5, No.3, pp.185193.
Trihandini, R. A. F. M. 2005. Analisis Pengaruh Kecerdasan Intelektual, Kecerdasan Emosi, dan Kecerdasan Spiritual terhadap Kinerja Karyawan (Studi Kasus di Hotel Horison Semarang). Tesis Tidak Diterbitkan. Semarang: Universitas Diponegoro.

Zohar, D., dan Marshal, I. 2009. SQ Memanfaatkan Kecerdasan Memaknai Kehidupan Terjemahan Rahmi. Bandung: Kronik Indonesia Baru, cet.Ke-1, hlm20. 